左右肺で異なった組織型を示した肺癌の 一剖検症例

\begin{tabular}{llllllll}
\multicolumn{10}{c}{ 関西医科大学第 1 内科学教室 } \\
畑 & 一 & 米 & 津 & 精 & 文 & 大久保 & 進 \\
粉 $川$ 皓 & 年 & 岡 & 本 & 緩 & 子 & 大 久保 & 滉
\end{tabular}

関西医科大学第 2 病理学教室 駒井義彦森井外吉

\section{緒悪}

原発性肺癌で組織型の異なるものが重複した症例の頻 度は肺癌全体の $1 \%$ 以下とされ，さらに左右肺でそれぞ れ異なった組織型を示す症例の頻度はさらに低い.

われわれは, 入院時胸部 X線所見, 胸部CTなどによ り腺癌を最も疑ったが，喀痰細胞診で扁平上皮癌の所見 を得た症例で，剖検にて左右肺にてそれぞれ異なった組 織型を示した原発性重複肺癌の一症例を経験したので報 告する.

\section{症例}

患 者: 62才, 男子, 生命保険会社外交員

主 訴: 右背部痛

既往歴：1967年より肺結核で約 2 年間加療

家族歴：姉が肺炎で死亡

現病歴：1977年頃より咳嗽，喀痰が出現しだしたが他 に症状なく放置. 1979年 9 月頃より右背部〜側胸部にか けての持続痛を自覚. 発熱(一), 咳嗽・喀痰の増強 (一). 同年11月頃より疼痛のため不眼をきたすようになり，11 月中旬開業医より胸部 X線検査で異常陰影を指摘され11 月 22 日紹介されて当科受診. 肺癌の疑いで 12 月 13 日入院. 食思良好. 酒 3 合/日. タバュ20３0本/日. 便通 1 日 1 回.

入院時現症：体格： $168 \mathrm{~cm}, 49.5 \mathrm{~kg}$. 脈拍： 80 , 整, 緊張正常. 皮䖉・結膜: 正常. 手指: バチ状指 $(+)$. 爪 : チアノーゼ(一). 咽頭・扁桃 : 正常. 舌苔 : 著明. 甲 状腺腫 (一), 表在リンパ節触知せず. 心濁音界：やや 小. 肺肝境界 : 第UII助骨. 心音 : 正常. 肺野 : 右背下部 に呼吸音減弱と声音振戦減弱, 右背下部に（自発痛に一 致して）圧痛 $(+)$ ．腹部：肝・脾・腎触知せず，下腿の
浮腫 (一), 下腿外側に湿疹様皮疹 $(+)$, 膝蓋腱反射・丁 キレス腿反射共に低下を認めるが，その他神経学的に異 常所見を認めない。

入院時検査所見：表 1 亿示すように，貧血なく，䀒腎 機能に異常を認めないが，赤沈中程度え進， CRP は十 1, CEA は33.3と上昇, 一方, PPD 皮内反応は陽性, PHA 皮内反応陽性, 喀痰細胞診で Class V, 角化扁平 上皮癌の所見を得た.

胸部X線写真では，Photo. 1 亿示すように，両上肺野 に陳旧性肺結核による多数の結節様陰影と, 同部へ向う 肺門からの索状陰影があり，右中下野で縦隔寄りに淡い 陰影を認めるが，その中の肺紋理は消失することなく十 分に観察出来，肺外病变であることを示唆させた。 ま た，左肺では左肺門の低下と左中下野の浸潤陰影を認め た.

Photo. 2 に示すように, 右肺では中央より右に $3 \mathrm{~cm} の$ 側面断層にて，第 9 胸椎の高さに腫瘤様陰影を認め，そ れより下部に浸潤様ないしは腫溜様陰影を認めた。背面 より $5 \mathrm{~cm}$ の右肺正面断層では概ね一塊となった腫瘤様陰 影を認め, 第 9 肋骨の一部に侵蝕像を認めた.

Photo. 3 亿示すように, 左肺では, 正中より左 $7 \mathrm{~cm} の$ 側面断層で下葉の容積減少, air bronchogramを認めた. 背面より $5 \mathrm{~cm}$ 正面断層で下葉の部位に一致して浸潤様 陰影を認めた。

このように左右肺野ではX線所見上異なった様相を呈 した. 左肺下葉の所見は腺癌を疑わせる所見であった.

一方，表 2 亿特殊検査の所見を示す. 胸部 CT scan の所見では，X線写真で得られた所見以外に第 9 胸椎へ の浸潤と右肺背面に胸膜の腫瘤を考えさせる所見を得た (Photo. 4 ).

入院後の経過（表 3 ）：右背部痛はさらに増強. 12月 
第 1 表 入院時検査所見

\begin{tabular}{|c|c|c|c|c|c|c|c|}
\hline WBC & 7300 & GOT & 25 & $\Omega N$ & 10 & RA & $(-)$ \\
\hline $\mathrm{RBC}$ & $451 \times 10^{4}$ & GPT & 11 & Creat. & 0.8 & CRP & $(+)$ \\
\hline $\mathrm{Hb}$ & 15.1 & ALP & 173 & UA & 3.7 & ASLO & 160 \\
\hline $\mathrm{Ht}$ & 43.1 & LAP & 63 & & & & \\
\hline Eo & 2 & T. BII & 0.7 & $\mathrm{Ca}$ & 4.5 & $\mathrm{TP}$ & $7.2 \mathrm{~g} / \mathrm{dl}$ \\
\hline St & 10 & D. BII & 0.2 & $\mathrm{Mg}$ & 2.1 & Alb & 50.6 \\
\hline Seg & 44 & LDH & 324 & $\mathrm{P}$ & 3.0 & $\alpha_{1}$ & 4.2 \\
\hline Ly & 38 & $r$-GTP & 38 & $\mathrm{Na}$ & 141 & $\alpha_{2}$ & 9.2 \\
\hline Mo & 6 & Ch-E & 3914 & $\mathrm{~K}$ & 3.9 & $\beta$ & 10.8 \\
\hline Reticulo & $6 \%$ & ZTT & 12.8 & CI & 101 & $r$ & 25.0 \\
\hline Platelet & 219. 000 & & & & & $\mathrm{~A} / \mathrm{G}$ & 1.02 \\
\hline & & & & & & $1 \mathrm{gG}$ & 1393 \\
\hline CEA & 33.3 & \multirow{2}{*}{\multicolumn{2}{|c|}{$\alpha$-Fo $(-)$}} & & & $1 \mathrm{gA}$ & 562 \\
\hline ESR & $1^{\circ} 40 \quad 2^{\circ}$ & & & & & $1 \mathrm{gM}$ & 95 \\
\hline \multicolumn{8}{|c|}{ EKG $:$ LVH, ST $\downarrow$ in $V_{5-6}$} \\
\hline \multirow{2}{*}{ 喀痰 $\left\{\begin{array}{l}\mathrm{E} \\
\mathrm{K} \\
\mathrm{x}\end{array}\right.$} & \multirow{2}{*}{\multicolumn{3}{|c|}{$\begin{array}{l}\text { Enterobactor cloacae }(-), \\
\text { Klebsiella aerogenes ( } 1 \text { colony) } \\
\text { 結核菌 (-) }\end{array}$}} & & & 血液ガス & \\
\hline & & & & & & P H & 7.419 \\
\hline \multirow{2}{*}{\multicolumn{4}{|c|}{ P P D 皮内反応 $\frac{14 \times 14}{34 \times 38}$}} & & & $\mathrm{Po}_{2}$ & 73.0 \\
\hline & & & & & & $\mathrm{PcO}_{2}$ & 39.3 \\
\hline \multirow{2}{*}{\multicolumn{6}{|c|}{ P H A 皮内反応 $\frac{25 \times 30}{35 \times 42}$ で陽性 }} & $\mathrm{HCO}_{3}^{-}$ & 25.1 \\
\hline & & & & & & $\mathrm{Co}_{2}$ Cont. & 26.3 \\
\hline \multicolumn{6}{|c|}{ 胃腸透視 : Gastritis atrophicans } & B E & 0.8 \\
\hline \multicolumn{6}{|c|}{ 喀痰細胞診 Class V, Keratinized } & $\mathrm{SaO}_{2}$ & 93.7 \\
\hline
\end{tabular}

第 2 表 特殊 検 查所見

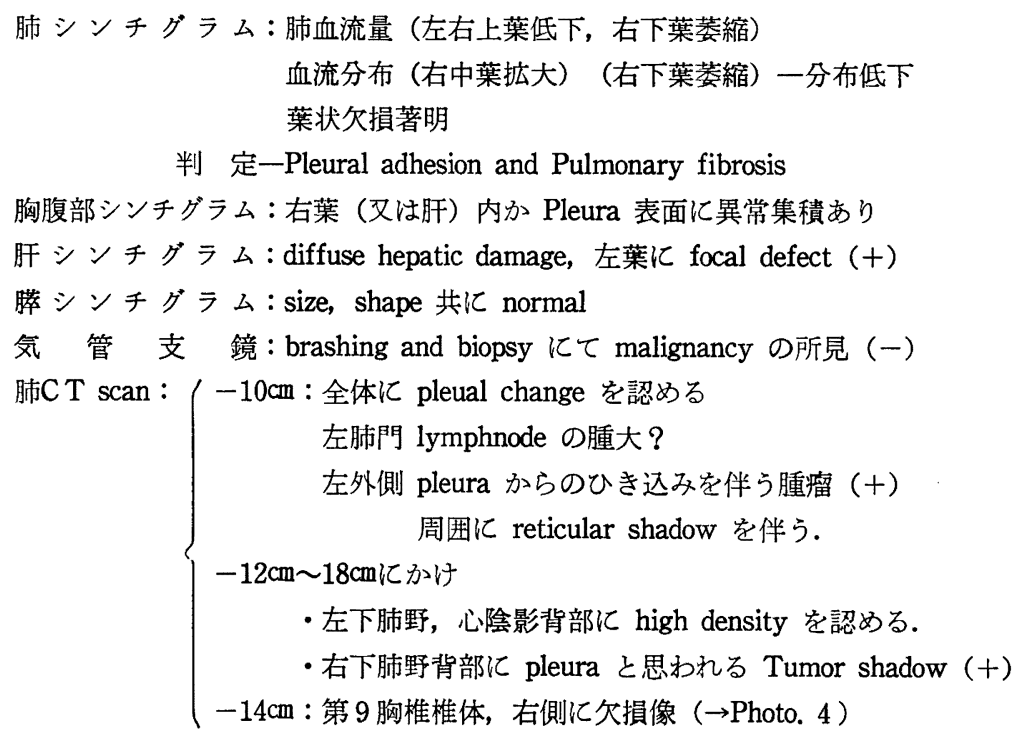


第 3 表 臨 床 経 過（症例 : 太○岩○ 今 62才）

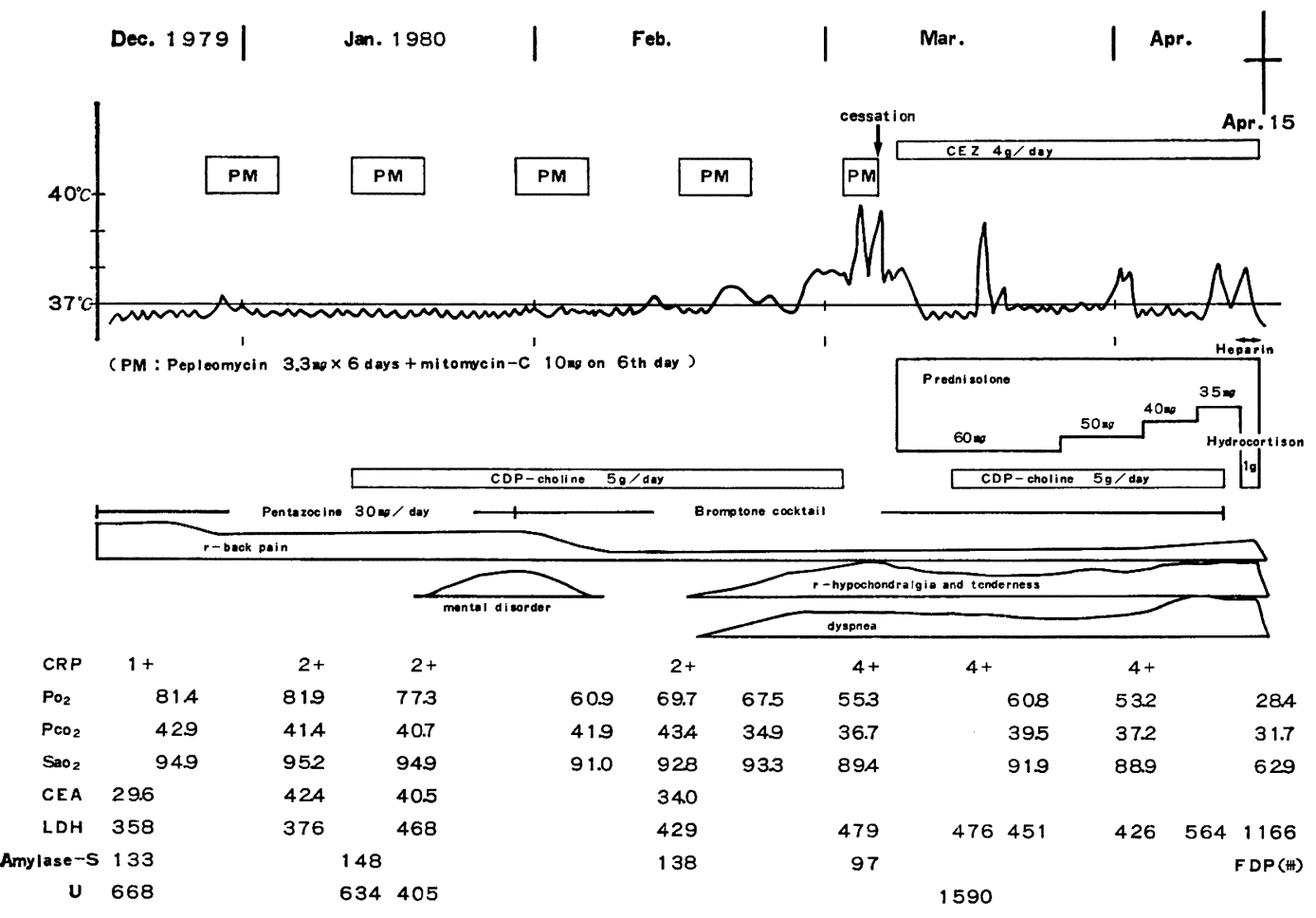

28日に気管支鏡ならびに生検を行ったが有意な所見は得 られなかった，喀痰細胞診では常に Class IV〜Vの角化 扁平上皮癌の所見を呈していたため，12月29日より， Pepleomycin と Mitomycin-C によるいわゆるPM療法 を開始した. 1980年1月末より両肺下野に Velcro ラ音 を軽度に聴取するようになり，2 月29日より $37^{\circ} \mathrm{C}$ 台の微 熱が出現， 3 月 3 日 P M療法第 5 クール目開始時, 悪感 戦慄を伴う $39^{\circ} \mathrm{C}$ 以上の発熱を来たし PM療法を中止し た. 両背部での Velcro ラ音はさらに増強し, 右季肋部 の圧痛, 叨打痛を認めるようになった。肺混合感染, 肺 線維症, 胆道感染症を疑い, Cefazolin 1 日 $4 \mathrm{~g}$, Prednisolone 1 日60mgを開始, 下熱を認めたが, それ以後も 右季肋部の吒打痛は持続し又, 週 1 回程度の発熱をきた すようになり，呼吸困難も伴うようになった。 4 月に入 って右季胁部痛, 体動時の呼吸困難が増強し 4 月 12 日 D I Cが関与したと考えられる急性呼吸不全のため死亡 した.

剖検診断は表 4 に示すようで, 右肺には $S_{6}$ 付近に原 発したと考えられる類表皮癌があり, 肺内病变部では Photo. 5 に示すように角化は認められなかった. Photo. 6 は右肺割面を縦隔側より見たものであるが，浸潤転移
第 4 表 : 剖検診断（剖検番号 関西医大 2722）

1 肺原発性重複癌 :
a．左肺下葉クルミ大高分化型腺癌
b. 右肺下葉拇指頭大類表皮癌

2 同上浸潤転移

1 (a) : なし

1 (b ) : 心霊（透明心囊水 $80 \mathrm{ml}$ ), 横隔膜, 第 9 肋骨および第 9 胸椎

3 D I C (死因)

両腎, 両肺, 胸膜, 胃, 膵, 前立腺に沉発

4 多発性胃急性潰瘍（血性内容 $600 \mathrm{~m} \ell$ )

5 間質性肺炎および陳旧性肺結核, 両側癒着性胸膜炎

6 東洋絞窄肝および単発性肝襄胞 (径 $3 \mathrm{~cm}$ )

7 全身動脈硬化症, 内分泌器官および精巣萎縮

8 大腸メラノーシス

は横隔膜, 心簑, 第 9 肋骨, 第 9 胸椎に及び, Photo. 7 は横隔膜付近の組織像を示すが，これらの浸潤転移巣で は角化傾向が著明であった. Photo. 8 は, 左肺割面を縦 隔側より見たものであるが, 左下葉にくるみ大の腫瘍浸 
第 5 表 左右肺で異なった組織型を示した重複肺癌症例 （1976年～1977年 日本病理剖検輯報より）

\begin{tabular}{|c|c|c|c|c|}
\hline 症 例 & 年 齢 & 性 別 & 組 & 型 \\
\hline & & & 右 & 肺 \\
\hline 1 & 80 & 女 & 多型細胞癌（上)※ & 痁（上） \\
\hline 2 & 69 & 男 & 大細胞性未分化癌（下） & 扁平上皮癌（下） \\
\hline 3 & 72 & 男 & 大細胞性低分化腺癌（上） & 大細胞癌（上） \\
\hline 4 & 68 & 男 & 小細胸 癌 (下) & 腺癌（乳頭腺管腺癌）（上） \\
\hline 5 & 68 & 男 & 扁平上皮癌（上） & 小細胞未分化癌（上） \\
\hline 6 & 75 & 男 & 小細胞未分化癌 (下) & 腺癌（切除術後）（下） \\
\hline \multirow[t]{2}{*}{7} & \multirow[t]{2}{*}{73} & \multirow[t]{2}{*}{ 男 } & \multirow[t]{2}{*}{ 小 細胞癌（下） } & 扁平上皮癌 (下) \\
\hline & & & & 腺癌（上） \\
\hline
\end{tabular}

※（）内は上中下葉の別

潤を認め，その組織所見はPhoto. 9 亿示すように細気 管支原発を想定させる高分化型腺癌であった，左右とも 肺門リンパ節転移は認められず，また，検索しえた範囲 では両肺に腺癌と類表皮癌の移行ないし衝突を示唆する 所見は認められなかった。

\section{考按}

重複癌の定義については, 古くは Billroth'1) 記記載し ているが, 現在では Warren and Gates ${ }^{2}$ のものが広く 支持され，それ注，(1)のおのの腫場は明らかに悪性の 像を示すこと(2)打互いが離れて存在すること(3)一方が他 方の転移であるものは除外することとしている。一方，

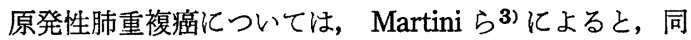
時性に，あるいは異なった時期に，異なった部位で，異 なった組織型を示せばよいとされている，本症例は，X 線所見より右肺外腫瘍と左肺下葉の腺癌が疑われ，喀痰 細胞診では角化扁平上皮落の所見を得た症例で，剖検に より右肺外病変と考光られたものは, 右下葉の $\mathrm{S}_{6}$ 付近 より原発したと考えられる類表皮癌の浸潤で，一方左肺 下葉の腫滇からは高分化型腺癌の組織所見を得, 左右そ れぞれ他方の転移を示唆する所見は検索し得た範囲では 証明されなかったもので, 原発性肺重複癌の一症例と考 えられた。

肺重複癌の例数については，1968年の成毛の集計4)で 89例, 1971年の松田の集計5) で120例と報告されている.

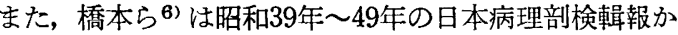
ら原発性重複肺癌の18症例を集計し，そのうち類表皮癌 十腺癌の組合せは10例であったという。なお，Martiniら 3) は Sloan-Kettering Cancer Center の Memorial Hospitallおおる1955年〜1974年の原発性多発性肺癌は50例 で，肺癌全体例の $1 \%$ 以下であり，そのうち本症例にみ られたように左右肺でそれぞれ異なった組織型を示す重 複肺澢は同時発生のもの 3 例, 異時発生のもの 7 例であ るとしている. 関西医大病理の森井らで は，1958～1965 年にみられた27例の肺癌剖検例のうち 5 例に重複癌を認 めたがそのうち原発性重複肺癌と考元られたすのは 1 例 であったという．今回，われわれは，1976年～1977年の 重複肺癌の症例を, 日本病理剖検輯報8)で調查したとこ ろ, 肺癌で死亡した患者 3,720 例のうち, 重複肺癌が 22 例 $(0.6 \%)$ であった。 また左右の肺で組織型が異なって いる重複肺癌婊 4 亿示すように，異時発生之考元られ る症例 6 を除くと，6例 $(0.16 \%)$ であった.

\section{結語}

以上，左右肺で組織型が異なり，2つの組織間におい て連続性が認められなかった原発性肺重複肺癌の一症例 を報告し，文献的考察を加えた。

なお本論文の要旨は, 第 103 回日本内科学会近畿地方 会（昭和55年12月）で発表した。 
文献

1) Billroth, H. : Die allgemeine chirurgie, $\mathrm{Pa}$ thologie und Therapie, R. Reimer, Berlin, 1889.

2) Warren, S. and Gates, O. : Multiple primary malignant tumors : A survey of the literature and a statistical study, Am. J. cancer, 16, 1358 1414, 1932.

3) Martini, N. and Melamed, M. R. : Multiple primary lung cancers, J. Thoracic and Cardiovascular Surgery, 70, 606 612, 1975.

4）成毛燳夫，末舛恵一他：同時に多発した原発性肺 癌の 3 例, 日本胸外会誌, 16, 153〜 164, 1968.
5）松田 実, 宝来 威他：原発性両側性肺癌の2 例, 癌の臨床, 17, 557〜 561, 1971.

6）橋本武志, 小林庿次ら：原発性重複肺癌一一剖検 例の報告と重複癌についての統計的観察—, 癌 の臨床, 22, 1370 1375, 1976.

7）森井外吉, 高田霞子ら：27肺癌剖検例にみられた 重複癌 5 例, 関西医科大学雑誌, 18, 34 43, 1966.

8）日本病理剖検輯報第19輯, 第20輯, 日本病理学会 編, 日本病理剖検輯報刊行会, 東京, 1976 1977. 


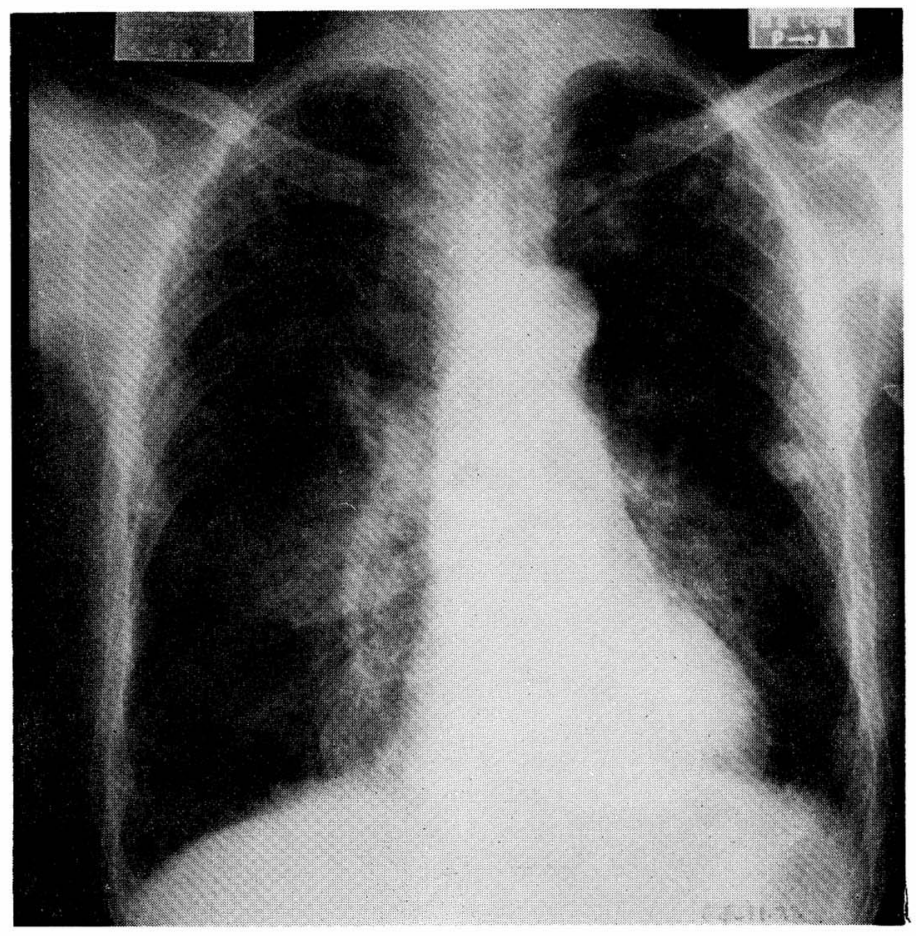

Photo. 1 : Chest Plain X-ray film on admission

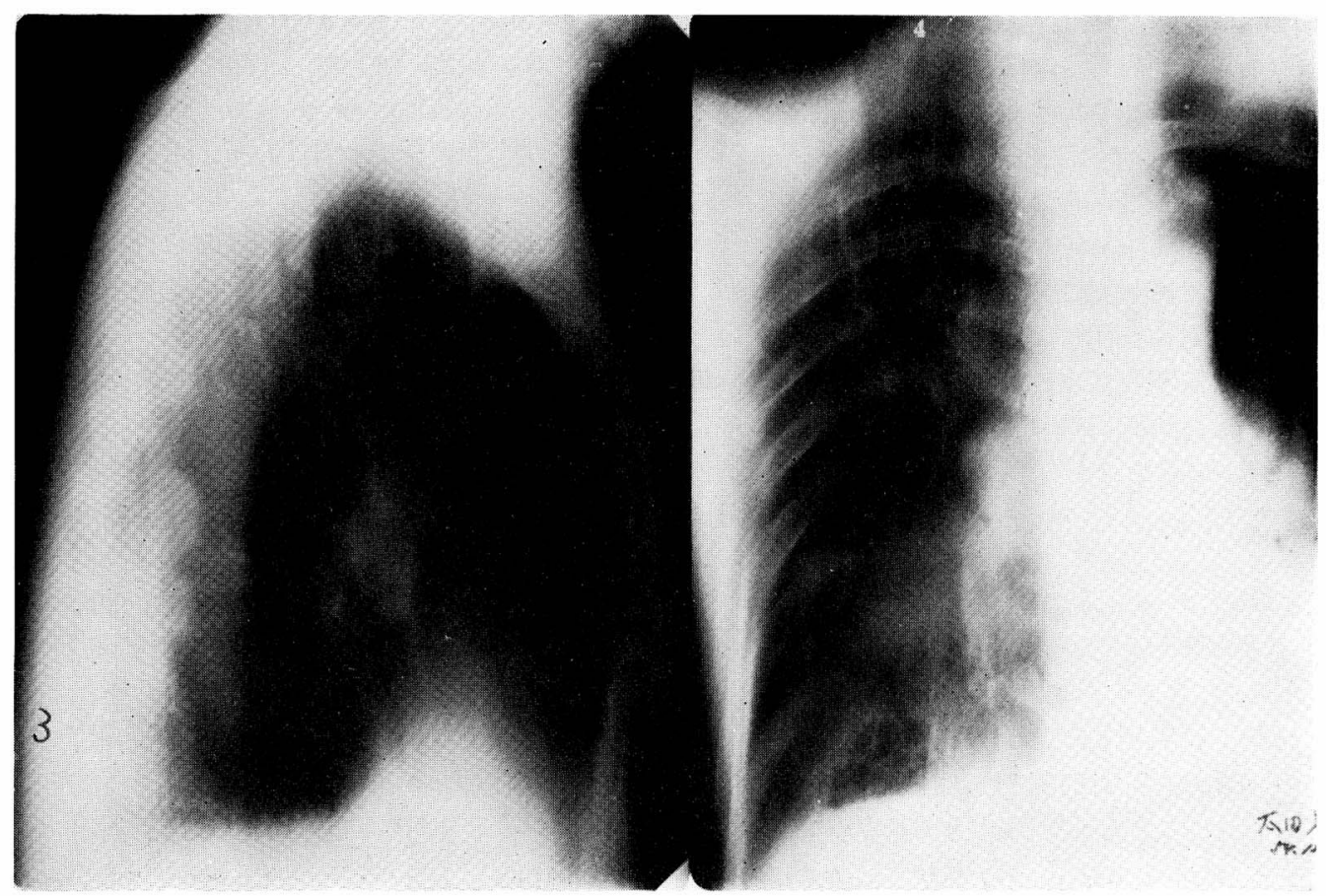

Photo. 2 : Tomogram of the right lung 


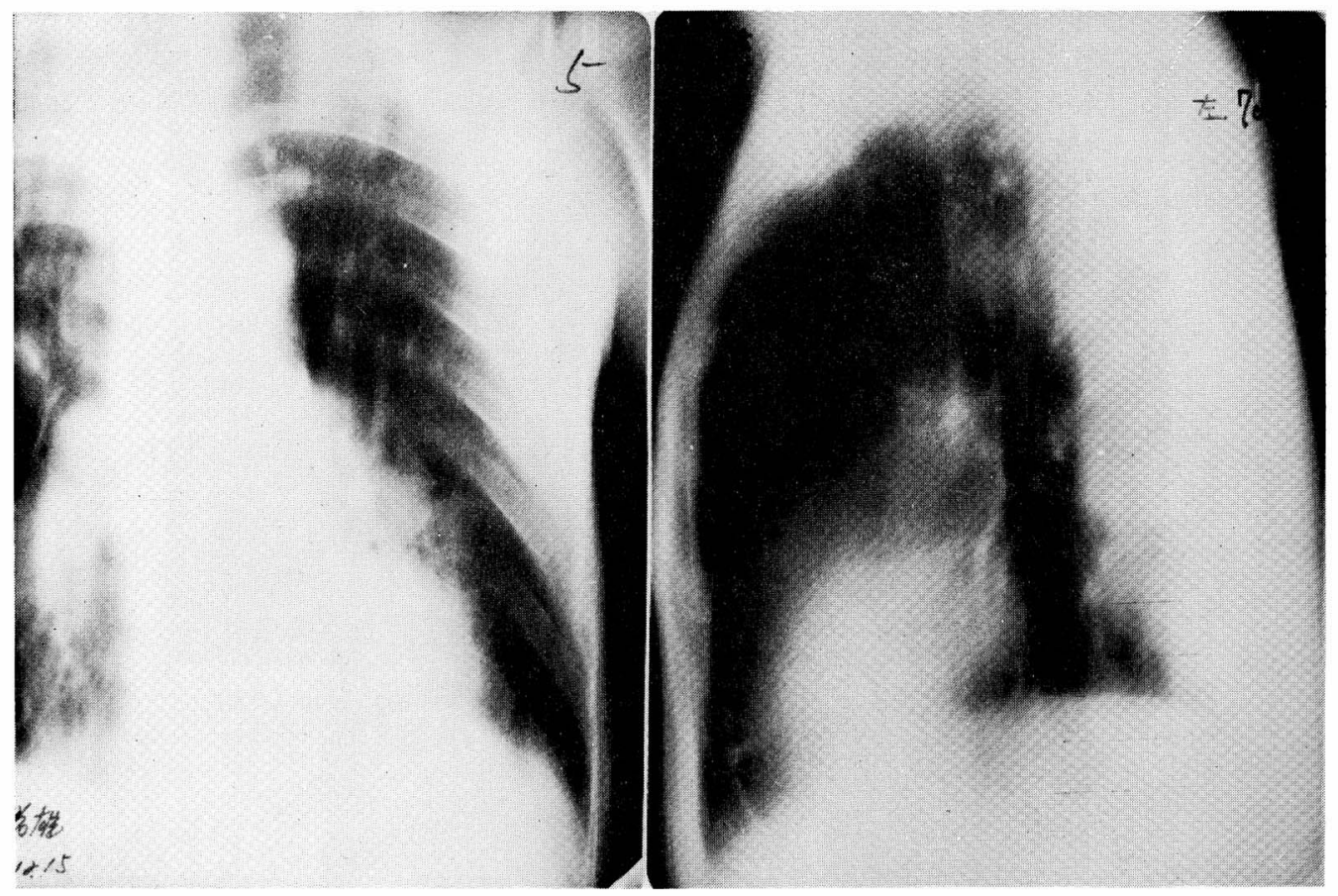

Photo. 3 : Tomogram of the left lung

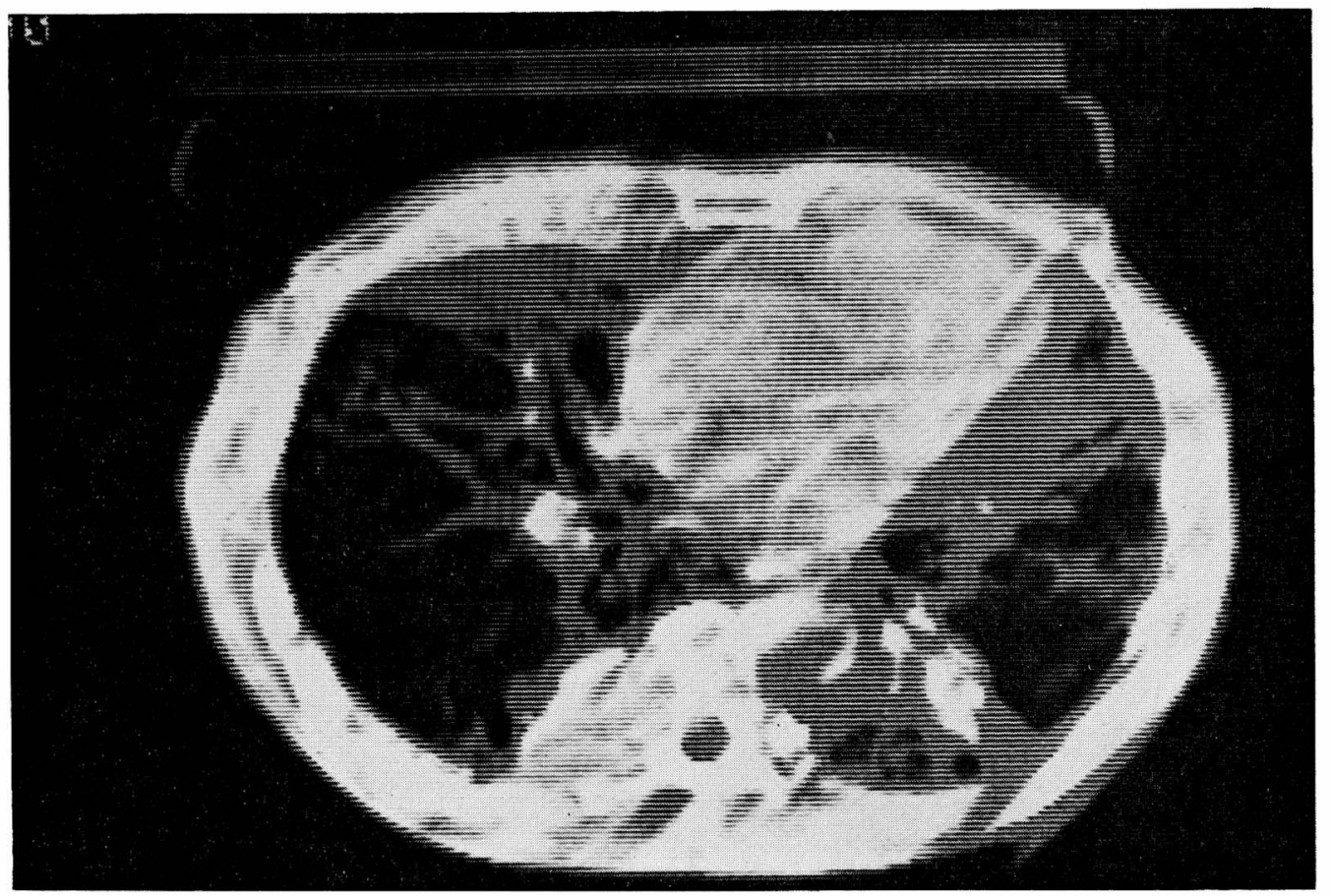

Photo. 4 : Computerized tomogram of the lung $(-14 \mathrm{~cm})$ 


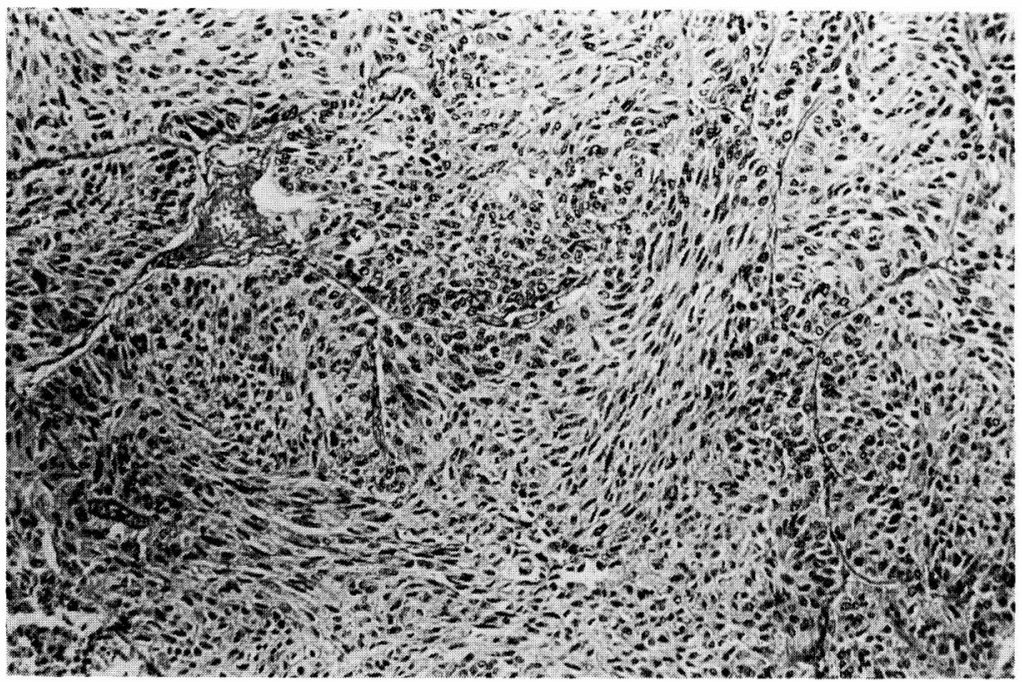

Photo. 5 : Epidermoid carcinoma in the $S_{6}$ region of the right lung $(\times 100)$

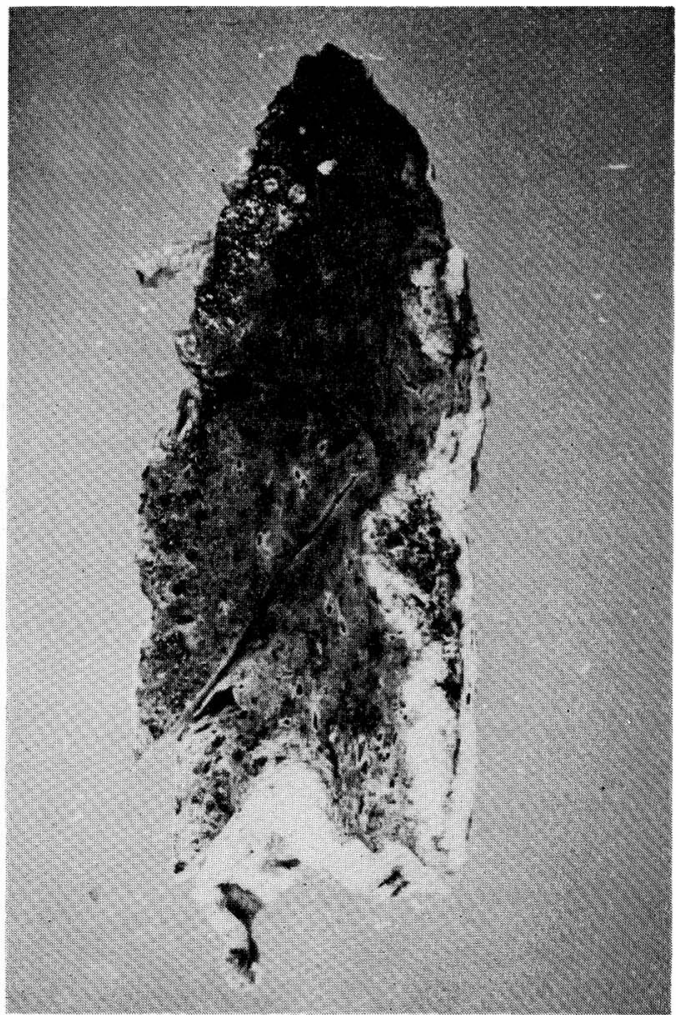

Photo. 6 : Lateral section of the right lung

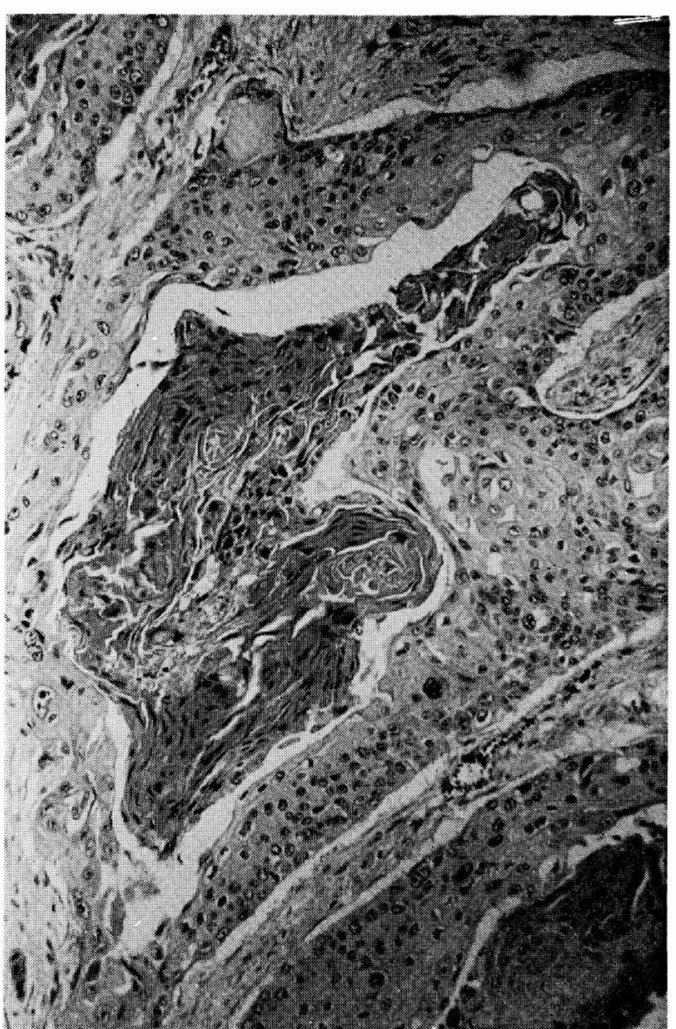

Photo. 7 : Epidermoid carcinoma in the diaphragm. ( $\times 100)$ Keratinization is remarkable 


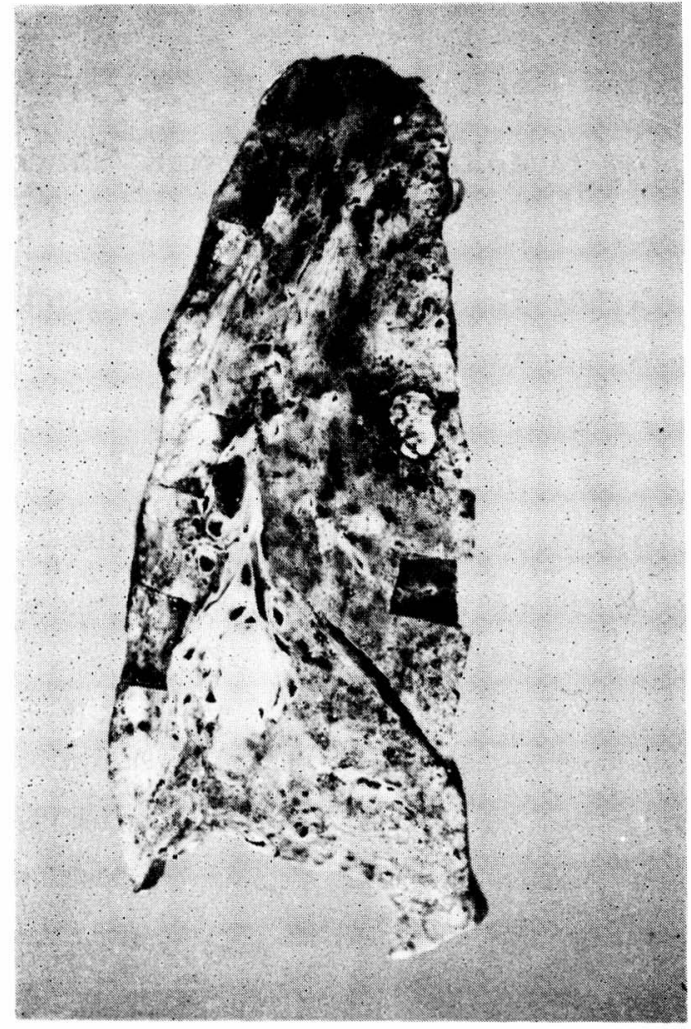

Photo. 8 : Lateral section of the left lung

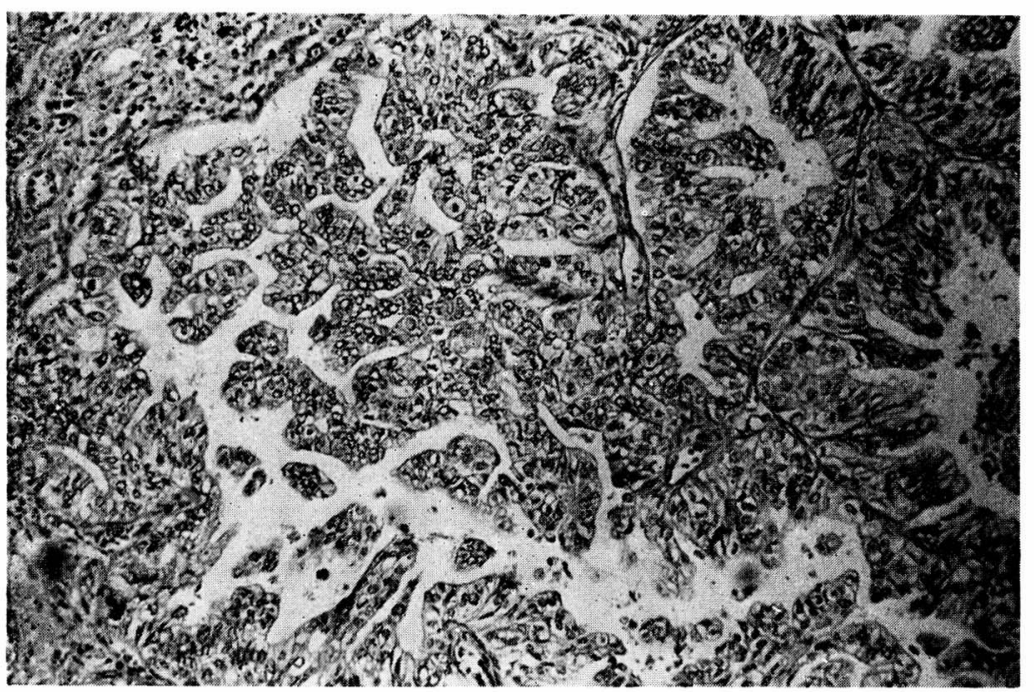

Photo. 9 : Well differentiated adenocarcinoma in the lower lobe of the left lung $(\times 100)$ 
（欧文抄 録）

\title{
An Autopsy Case of Each Lung Independently Developing Histologically Different Cancers
}

\author{
Hajimu Hata, Seybun Yonezu, Susumu Okubo, Terutoshi Kokawa, \\ Yuruko Okamoto and Hiroshi Okubo
}

1st Department of Internal Medicine, Kansai Medical University, Moriguchi, Osaka, Japan

Yoshihiko Komai and Sotokichi Morii

2nd Department of Pathology, Kansai Medical University,

Moriguchi, Osaka, Japan

A 62 year old male was hospitalized on Dec. 13, 1979. He was complaining of back pain and his previous doctor had pointed out an abnormal shadow on his chest X-ray film.

Although cytological examinations of the patient's sputum revealed Pap. Class IV-V, a keratinized squamous cell carcinoma of the lung, his plain chest $\mathrm{X}$-ray examination, tomography and computerized tomography suggested the presence of a possible extrapulmonary tumor on the right lung and adenocarcinoma in the lower lobe of the left lung.

Lab. data : liver and renal functions normal

$\begin{array}{ll}\text { CRP } & 1+ \\ \text { CEA } & 33.3 \\ \text { PPD skin test } & \text { positive } \\ \text { PHA skin test } & \text { positive } \\ \text { blood gas analysis } & \text { within normal limit }\end{array}$

He was treated with Pepleomycin and Mitomycin-C regimen (PM regimen). After the 5th course of PM regimen, his genral condition deteriorated. The patient died of respiratory failure on April 15, 1980 and the autopsy revealed that he had suffered from bilateral, primary double lung cancer. A epidermoid carcinoma, which originated from the $\mathrm{S}_{6}$ region of the right lung, had invaded right pleural cavity, the diaphragm, the percardium, the right IXth rib and the IXth thoracic vertebrae. On the other hand, a well differentiated adenocarcinoma was located mainly in the lower lobe of the left lung. Microscopic examination revealed no evidence, in either lung, of metastatic sites from the cancer of the opposite lung. In addition, the hilar lymphnodes were determined to be free of any metastatic sites from either lung.

Primary double lung cancer is of very rare incidence. In Japan, in 1976 and in 1977, it was 
found in autopsy reports in approximately $0.6 \%$ of all lung cancer cases. The percentage of occurence drops even lower to $0.16 \%$ for primary double lung carcinomas, in which each lung has independently developed histologically different cancers. 